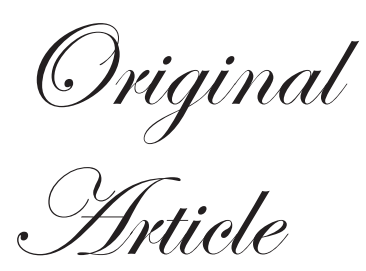

${ }^{1}$ Department of General Surgery, St. John's Medical College Hospital, Sarjapur Road, Bangalore-34, India. ${ }^{2}$ Division of Infectious Diseases, St. John's Research Institute, Sarjapur Road, Bangalore-34, India.

Correspondence: Abheesh Varma Hegde Email:abhi.vhegde@gmail.com

\section{H. Pylori in gall bladder: the answer to the Indian divide?}

\author{
Abheesh Varma Hegde ${ }^{1}$, Syed Fazil Ahamed ${ }^{2}$, Ann \\ Sunny ${ }^{1}$, Rosario Vivek ${ }^{2}$, Rozario Anthony ${ }^{1}$
}

ABSTRACT

Background: Helicobacter pylori has been established as an etiological agent in gastric adenocarcinoma and MALT lymphoma in the stomach. Recent reports have implicated this bacterium in the causation of benign and malignant gall bladder disease.

Aim: To study the prevalence of H. pylori in South Indian patients with gall bladder pathology presenting for cholecystectomy at a tertiary care hospital and to correlate $H$. pylori colonization of gall bladder with histopathologic changes.

Methods: 94 patients presenting for cholecystectomy at St. Johns Hospital Bangalore over a period of two years, were enrolled in to the study. Gallbladder tissue was taken immediately after cholecystectomy and subjected to analysis by DNA PCR, histopathology and rapid urease test (RUT) for presence of $H$. pylori.

Results: Among the 94 patients included in the study mean age of the study population was found to be 45 years. $61(64.9 \%)$ were females and $33(35.1 \%)$ were males. $81.9 \%$ underwent laparoscopic cholecystectomy. $87 \%$ had chronic cholecystitis. Out of the total 94 specimens analyzed for H. pylori, DNA PCR and HPE were negative in all the samples. RUT was positive in four gallbladder tissue samples.

Conclusion: H. pylori was not found in gall bladder of patients with benign gall bladder disease in South Indian population.

KEYWORDS: Biliary; cholelithiasis; inflammation; H. pylori.

\title{
Introduction
}

Marshall and Warren were the first to prove conclusively that $H$. pylori was the etiological factor for gastritis and peptic ulcer disease. Since then, H. pylori has been implicated in the development of gastric adenocarcinoma and MALT lymphoma in the stomach. ${ }^{1}$ The prevalence of infection in the digestive tract by Helicobacter 
species varies in the population studied, suggesting epidemiological differences in the distribution of the bacillus in various countries. So far, $H$. cinaedi, $H$. fennelliae, $H$. canis, $H$. rappini, $H$. pullorum, and $H$. canadensi have been isolated from human intestinal tracts. $^{2}$

It is hypothesized that a relationship like that of $H$. pylori and gastric carcinoma exists in the gall bladder. According to this, H. pylori is a causative agent of gallbladder cancer by causing chronic cholecystitis due to gall stones and later developing dysplasia, metaplasia and carcinoma. It raises chances of potential prevention of this disease by eradication of $H$. pylori through medical therapy. Also, clinicians treating patients with gastric H. pylori infection need to be aware that associated gall bladder disease may need attention at the same time. The highest incidence of gallbladder cancer is found in women living in India, Pakistan and Ecuador. ${ }^{2,3}$ Given the burden of the disease, studies on the association between $H$. pylori and gallstone pathology have gained importance. The aim of this study was find the prevalence of $H$. pylori in South Indian patients with gall bladder pathology presenting for cholecystectomy at a tertiary care hospital.

\section{Methods}

A total of 94 consecutive patients presenting for cholecystectomy at St. Johns Medical College Hospital for Gall bladder disease were enrolled into the study between June 2014 and June 2016. Sample size was estimated using the $\mathrm{N}$ master software. The values for sample size estimation were obtained from the study by Bansal et al. $^{4}$ The sample size required with $10 \%$ precision and $95 \%$ confidence interval was found to be 85 . North Indian patients who underwent surgery were excluded. Only patients hailing from Karnataka, Kerala, Tamil Nadu, Andhra Pradesh were considered. The study was approved by institutional ethics committee.

\section{Protocol}

Patients presenting for a cholecystectomy were approached and informed consent taken for enrollment into the study. Demographic data and history of symptoms, co morbidities was taken and the liver function tests and ultrasound report noted in the data sheet. Intra operatively, immediately after gall bladder retrieval, two tissue pieces were taken from the fundus of the gall bladder. One for DNA PCR was put into an eppendorf tube and snap freezed immediately by putting it into a container with liquid nitrogen in it. This was later transferred into a deep freezer maintaining samples at $-80^{\circ} \mathrm{C}$ till DNA PCR analysis was carried out. The second tissue piece was put into a tube containing rapid urease reagent. The change of color of the reagent from yellow to pink at the end of half hour was taken as urease positive. The remaining gall bladder tissue was sent for routine histopathological analysis during which Modified Giemsa staining was carried out to detect presence of $H$. pylori.

For $H$. pylori specific PCR, among the several $H$. pylori specific primer sets targeting the 16S rRNA gene, forward primer $27 \mathrm{f}$ (59-AGAGTTTGATCMTGGCTCAG-39) and reverse primer HPY (59-CTGGAGAGACTAAGCC CTCC-39) were used. DNA extraction was performed using the commercially available QiagenQIAamp Mini kit (Qiagen Crawley UK). Tissue samples were cut to size to weigh less than $20 \mathrm{mg}$. Biopsy samples were kept frozen until the addition of ATL buffer before allowing biopsies to equilibrate to room temperature, an additional $10 \mathrm{ml}$ of Proteinase K was added for an initial lysis period of 18 hours to ensure complete lysis of the biopsy material prior to DNA extraction following which PCR was performed. PCR was carried out with the following cycling conditions: initial denaturation at $94^{\circ} \mathrm{C}$ for $5 \mathrm{~min}$, followed by 35 cycles of $94^{\circ} \mathrm{C}$ for $1 \mathrm{~min}, 66^{\circ} \mathrm{C}$ for $1 \mathrm{~min}, 72^{\circ} \mathrm{C}$ for $2 \mathrm{~min}$ and a final extension at $72^{\circ} \mathrm{C}$ for $10 \mathrm{~min}$. The amplified product was analysed by agarose gel electrophoresis along with a DNA ladder and samples with a specific band of 800 base pair in length was considered as a positive for the presence of $H$. pylori.

\section{Results}

Among the 94 patients included in the study mean age of the study population was found to be 45 years. 61 (64.9\%) were females and $33(35.1 \%)$ were males. 77 patients (81.9\%) underwent laparoscopic cholecystectomy 
and only $17(18.1 \%)$ underwent an open procedure. 64 patients (68.1\%) hailed from Karnataka, 19 (20.2\%) from Andhra Pradesh, 7 (7.4\%) from Tamil Nadu and 4 (4.3\%) from Kerala.

Among the study group, 7 (7.4\%) patients had biliary pancreatitis, 4 (4.3\%) had CBD stones and underwent ERCP prior to surgery, 2 (2.1\%) had gallbladder polyps, $81(86.2 \%)$ patients underwent cholecystectomy for symptomatic cholelithiasis/calculous cholecystitis. On histology, 90 (95.7\%) had chronic cholecystitis, $2(2.1 \%)$ had empyema of the gallbladder, 1 (1.1\%) had adenocarcinoma of the gallbladder and 1 (1.1\%) gangrenous cholecystitis.

Rapid Urease test (RUT) was positive in 4 $(4.3 \%)$ patients out of the entire study population. Among them, 3 had chronic cholecystitis and 1 had gangrenous cholecystitis. Modified Giemsa staining and DNA PCR (Figure 1) did not detect H. pylori in any of the total 94 samples analyzed. The patient with adenocarcinoma of the gallbladder was found to be negative for $H$. pylori on Rapid Urease, Modified Giemsa staining and DNA PCR.

\section{Discussion}

The true prevalence and relationship of different species of Helicobacter in the pathogenesis of these diseases is not known. Stone formation depends on epidemiological, physical, chemical, nutritional, genetic, immunological and infectious factors. This last factor has been studied in populations where cholelithiasis and intra-hepatic lithiasis are common diseases and the infection by Helicobacter species very prevalent, as in Chile, Japan, China and Thailand. The condition most commonly predisposing for gallbladder cancer is cholelithiasis.

Researchers continue to discover new associations between $H$. pylori and idiopathic diseases, as well as potential benefits of $H$. pylori infection. Live $H$. pylori have been found in the peritoneal cavities of pseudomyxomaperitonei cancer patients, H. pylori DNA has been amplified from atherosclerotic plaques and the oral cavity for years. Evidence of H. pylori colonization has also been found in the gallbladder, ears, nose, skin, and even eyes. The significance of $H$. pylori in these locations is still debated. ${ }^{5}$

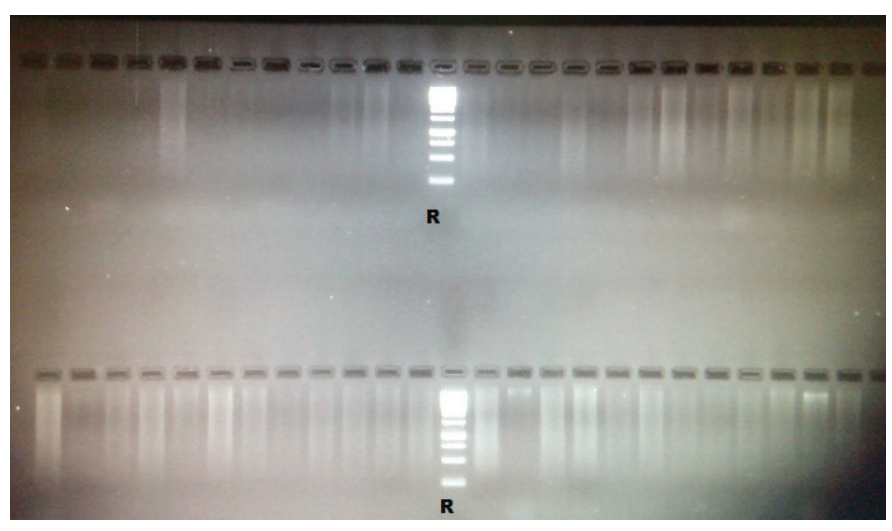

Figure 1: DNA ladder demonstrating negative results for the study population (40 samples are shown) (R Reference Band).

Bansal et $\mathrm{al},{ }^{4}$ found that culture, histology and rapid urease tests of bile and gallbladder specimens were negative for Helicobacter species in all patients. PCR for Helicobacter DNA was positive in $24.4 \%$ patients from bile and $32.6 \%$ patients from gallbladder specimens. Overall $H$. pylori was positive in $16(32.6 \%)$ patients with gallstone disease. Helicobacter DNA could not be identified in any of the controls using either bile or tissue PCR. None of the demographic, socioeconomic and etiological factors had any correlation with Helicobacter infection in bile and gallbladder tissue. They concluded that there was a high prevalence of $H$. pylori infection in the gallbladder in northern Indian patients undergoing cholecystectomy for benign gallbladder disease which was detected only by PCR. The study found an association between $H$. pylori in stomach and bile. It is thought that due to the strong coexistence of $H$. pylori in both bile and gastric mucosa, the bacteria may enter bile ducts by reflux from the duodenum. The other route of infection from gastric mucosa is thought to be hematogenous spread to the liver through portal circulation and then excretion into the bile. Mishra et al, ${ }^{6}$ in their study of 108 patients found that $24(44 \%)$ of gallbladder cancer and 18 (33\%) of gallstone disease patients grew $H$. pylori colonies on culture. On histology, H. pylori was found in 20 (37\%) gallbladder cancer and $15(28 \%)$ gallstone disease samples. The DNA PCR was done using the Hsp60-nested primers and was positive in $18(33 \%)$ gallbladder cancer and $15(28 \%)$ gallstone disease patients $(\mathrm{p}>0.05)$. Based 
on these results, the study group believed $H$. pylori was prevalent in a large population. Hence they concluded that H. pylori maybe endemic to the Varanasi region and may not play a significant role in the etiopathogenesis of gallbladder cancer in that region. In our study we did not find $H$. pylori in any of the 94 samples analyzed by DNA PCR and histopathological analysis.

Culture remains the definitive investigation to prove the viability of $H$. pylorii $\mathrm{n}$ bile and gall bladder tissue. It is possible that the number of bacteria remains very low and they may have been partially inhibited by adverse conditions in the biliary milieu. Other possibility is that there is patchy colonization of the biliary epithelium, thus culturing a small piece may not give positive results. Most other workers were also not successful in getting positive cultures, but could demonstrate DNA by PCR. The lack of recovery has been attributed to the prolonged freezer storage of tissue and bile without glycerol or other preservatives or that the DNA detected was from nonviable organisms.

Deeba et al, ${ }^{7}$ in their study were not able to isolate H. pylori in cultures from any of their patients. Direct microscopy was also found to be negative. Statistically significant difference was found between the prevalence of anti H. pylori $\mathrm{IgG}$ in the study group and the controls. There was increase in positivity for $H$. pylori IgG antibody with increasing age. The study group was not explored for the presence of acid-peptic disease. It was observed that $57.3 \%$ of the patients had titers of $>40 \mathrm{NTU} / \mathrm{ml}$ while only $30 \%$ of individuals in the control group had titers above $40 \mathrm{NTU} / \mathrm{ml}$. This is important suggesting that majority of patients of cholelithiasis in the study group were positive with higher titers. Our study did not analyze H. pylori in cultures and antibody testing was also not done due to its non specific nature.

Misra et $a 1,{ }^{8}$ found that $H$. pylori was present in 50 of $111(45 \%)$ sections with metaplasia. In sections containing $H$. pylori, adjacent to areas of metaplasia $6 \%$ showed acute inflammation and 58\% showed lymphoid follicle formation which was significantly higher than those sections without $H$. pylori. On molecular study, 8 out of 11 stones showed presence of $H$. pylori DNA with sequences like Indian strains of $H$. pylori. They concluded that $H$. pylori colonizes areas of gastric metaplasia in gallbladder producing histological changes like those in gastric mucosa. The isolation of $H$. pylori

\section{Table 1: Comparison of results of Indian studies}

\begin{tabular}{|c|c|c|c|c|c|c|c|}
\hline $\begin{array}{l}\text { Reference } \\
\text { (year) }\end{array}$ & Place & Method used & Disease & Specimen & $\begin{array}{l}\text { Organism } \\
\text { identified }\end{array}$ & $\begin{array}{l}\text { Helicobacter sp. } \\
(+) \text { in lithiasis } \\
\text { Group } \mathbf{n} / \mathbf{N}\end{array}$ & $\begin{array}{l}\text { Helicobacter sp. } \\
(+) \text { in Control } \\
\text { Group } \mathbf{n} / \mathbf{N}\end{array}$ \\
\hline $\begin{array}{l}\text { Misra } \\
(2007)\end{array}$ & Allahanbad & $\begin{array}{l}\text { HPE, IHC for } \\
\text { GB PCR for } \\
\text { GS }\end{array}$ & Cholecystitis & $\begin{array}{l}\text { Gall bladder } \\
\& \text { stones }\end{array}$ & H. pylori & $\begin{array}{l}\text { 50/111 (GB) 8/11 } \\
\text { (stones) }\end{array}$ & No controls \\
\hline $\begin{array}{l}\text { Deeb } \\
(2010)\end{array}$ & Aligarh & $\begin{array}{l}\text { HPE, Culture } \\
\text { ELISA }\end{array}$ & $\begin{array}{l}\text { Cholecystitis } \\
\text { Cholelithiasis }\end{array}$ & $\begin{array}{l}\text { Gall bladder, } \\
\text { Serum }\end{array}$ & H. pylori & \begin{tabular}{|l}
$0 / 75$ \\
$80 \%$ \\
(ELISA) \\
\end{tabular} & $\begin{array}{l}0 / 40 \\
47.5 \% \\
(\text { ELISA) } \\
\end{array}$ \\
\hline $\begin{array}{l}\text { Mishra } \\
(2010)\end{array}$ & Varanasi & $\begin{array}{l}\text { RUT, HPE, } \\
\text { PCR, culture } \\
\text { ELISA }\end{array}$ & \begin{tabular}{|l} 
Gallstone \\
disease, \\
Gallbladder \\
carcinoma \\
\end{tabular} & $\begin{array}{l}\text { Gall bladder, } \\
\text { Serum }\end{array}$ & H. pylori & $\begin{array}{l}18 / 54 \text { GBC } \\
15 / 54 \text { GSD }\end{array}$ & No controls \\
\hline $\begin{array}{l}\text { Bansal } \\
(2012)\end{array}$ & Delhi & $\begin{array}{l}\text { RUT, culture } \\
\text { HPE, PCR }\end{array}$ & $\begin{array}{l}\text { Benign } \\
\text { biliary } \\
\text { disease } \\
\end{array}$ & $\begin{array}{l}\text { Gall bladder } \\
\& \text { Bile }\end{array}$ & H. pylori & $16 / 49$ & $0 / 12$ \\
\hline $\begin{array}{l}\text { Choudhary } \\
\text { (2015) }\end{array}$ & Mullana & HPE & \begin{tabular}{|l|} 
Cholecystitis \\
Cholelithiasis \\
\end{tabular} & Gall bladder & H. pylori & $0 / 50$ & No controls \\
\hline $\begin{array}{l}\text { Present } \\
\text { study } \\
(2015)\end{array}$ & Bangalore & $\begin{array}{l}\text { RUT, HPE, } \\
\text { PCR }\end{array}$ & $\begin{array}{l}\text { Cholelithiasis } \\
\text { Gall bladder } \\
\text { carcinoma }\end{array}$ & Gall bladder & H. pylori & $0 / 94$ & No controls \\
\hline
\end{tabular}


DNA from these gallstones support the presence of the bacterium in the gallbladder. In the study done by Chaudhary et $\mathrm{al}^{9}{ }^{9}$ on histopathological examination no gall bladder mucosa demonstrated H. pylori in Giemsa staining. All 50 patients were negative by silver stain. On histopathological analysis of gall bladder samples in this study, adenocarcinoma was found in 1 sample only and metaplasia was not detected.

Table 2: Results of similar studies elsewhere

\begin{tabular}{|c|c|c|c|c|c|c|c|}
\hline $\begin{array}{l}\text { Reference } \\
\text { (year) }\end{array}$ & Country & $\begin{array}{l}\text { Method } \\
\text { used }\end{array}$ & Disease & Specimen & $\begin{array}{l}\text { Organism } \\
\text { identified }\end{array}$ & $\begin{array}{l}\text { Helicobacter sp. } \\
(+) \text { in lithiasis } \\
\text { Group } \mathbf{n} / \mathbf{N}\end{array}$ & $\begin{array}{l}\text { Helicobacter sp. } \\
(+) \text { in Control } \\
\text { Group n/N }\end{array}$ \\
\hline $\begin{array}{l}\text { Fox }^{11} \\
(1998)\end{array}$ & Chile & \begin{tabular}{|l} 
PCR \\
(16s rRNA)
\end{tabular} & $\begin{array}{l}\text { Cholecystitis, GB } \\
\text { carcinoma }\end{array}$ & $\begin{array}{l}\text { Bile, } \\
\text { Gallbladder }\end{array}$ & $\begin{array}{l}\text { H. bilis, } H . \\
\text { pullorum, } \\
\text { Flexispira } \\
\text { rappini }\end{array}$ & $10 / 32$ & No controls \\
\hline $\begin{array}{l}\text { Myung }{ }^{12} \\
(2000)\end{array}$ & Korea & $\begin{array}{l}\text { ELISA (H. } \\
\text { Pylori IgG) } \\
\text { PCR (Urea } \\
\text { A, 26KD } \\
\text { protein IHC } \\
\end{array}$ & $\begin{array}{l}\text { Hepatolithiasis } \\
\text { Choledocholithiasis }\end{array}$ & $\begin{array}{l}\text { Serum, } \\
\text { Bile, } \\
\text { Biliary, } \\
\text { Tissue, } \\
\text { Stone } \\
\end{array}$ & H. Pylori & $7 / 30$ & $0 / 8$ \\
\hline $\begin{array}{l}\text { Leong }^{13} \\
(2001)\end{array}$ & China & $\begin{array}{l}\text { PCR } \\
(16 \text { sRNA }) \\
\end{array}$ & Choledocholithiasis & Bile & $\begin{array}{l}\text { Helicobacter } \\
s p .\end{array}$ & $4 / 25$ & $0 / 4$ \\
\hline $\begin{array}{l}\text { Matsukura }^{14} \\
(2002)\end{array}$ & Japan & $\begin{array}{l}\text { PCR } \\
\text { (16sRNA) }\end{array}$ & Cholecystolithiasis & Bile & H. bilis & $18 / 42$ & $4 / 14$ \\
\hline $\begin{array}{l}\text { Presser } \\
\text { Silva }{ }^{15} \\
(2003) \\
\end{array}$ & Brazil & \begin{tabular}{|l} 
PCR \\
(16sRNA), \\
Culture \\
\end{tabular} & Cholelithiasis & $\begin{array}{l}\text { Bile, } \\
\text { Biliary } \\
\text { Tissue } \\
\end{array}$ & H. Pylori & $28 / 51$ & $2 / 18$ \\
\hline $\begin{array}{l}\text { Chen }^{16} \\
(2003)\end{array}$ & $\begin{array}{l}\text { New } \\
\text { Zealand }\end{array}$ & \begin{tabular}{|l|} 
PCR \\
$(16$ sRNA, \\
26KD \\
protein) \\
ELISA (H. \\
Pylori IgG) \\
\end{tabular} & Cholecystolithiasis & $\begin{array}{l}\text { GB Tissue, } \\
\text { Bile, Serum }\end{array}$ & H. Pylori & $35 / 70$ & $15 / 37$ \\
\hline $\begin{array}{l}\text { Farshad }^{17} \\
(2004)\end{array}$ & Iran & \begin{tabular}{|l} 
PCR \\
$(16$ sRNA) \\
\end{tabular} & Cholecystolithiasis & Stone, Bile & H. Pylori & $10 / 33$ & $0 / 40$ \\
\hline $\begin{array}{l}\text { Abayli }{ }^{18} \\
(2005)\end{array}$ & Turkey & \begin{tabular}{|l} 
PCR \\
(16sRNA) \\
IHC Culture \\
\end{tabular} & Cholecystolithiasis & $\begin{array}{l}\text { Stone, GB } \\
\text { Tissue }\end{array}$ & H. Pylori & $18 / 77$ & $0 / 20$ \\
\hline $\begin{array}{l}\text { Kobayashi }^{19} \\
(2005)\end{array}$ & Japan & \begin{tabular}{|l} 
PCR \\
(16sRNA, \\
Urea A) \\
\end{tabular} & Cholelithiasis & Bile & $\begin{array}{l}\text { H. Pylori, H. } \\
\text { bilis }\end{array}$ & $15 / 301 / 30$ & $2 / 210 / 21$ \\
\hline $\begin{array}{l}\text { Bohr }^{20} \\
(2007)\end{array}$ & Germany & \begin{tabular}{|l} 
PCR \\
(16sRNA) \\
IHC Culture \\
\end{tabular} & Cholecystolithiasis & GB Tissue & H. ganmani & $1 / 57$ & $0 / 22$ \\
\hline $\begin{array}{l}\text { Griniatsos }{ }^{21} \\
(2009)\end{array}$ & Greece & $\begin{array}{l}\text { PCR } \\
\text { (16sRNA) }\end{array}$ & Cholecystolithiasis & GB Tissue & H. Pylori & $4 / 89$ & $2 / 42$ \\
\hline $\begin{array}{l}\text { Karagin }^{22} \\
(2010)\end{array}$ & Sweden & \begin{tabular}{|l} 
PCR \\
$(16$ sRNA $)$ \\
\end{tabular} & Cholecystolithiasis & GB Tissue & $\begin{array}{l}\text { H. Pylori, H. } \\
\text { pullorum }\end{array}$ & $1 / 1006 / 100$ & $0 / 1020 / 102$ \\
\hline $\begin{array}{l}\text { Yakoob }^{23} \\
(2011)\end{array}$ & Pakistan & $\begin{array}{l}\text { PCR } \\
\text { (16sRNA) } \\
\text { IHC }\end{array}$ & Cholelithiasis & $\begin{array}{l}\text { Biliary } \\
\text { Tissue }\end{array}$ & H. Pylori & $23 / 88$ & $6 / 56$ \\
\hline
\end{tabular}


Pandey et $a,^{10}$ in their review of literature found that in the cumulative sample size of 205, 115 were positive $(56 \%)$ for Helicobacter, while among 263 controls 53 (20\%) were found to be positive for Helicobacter infection. The positivity rate in case control studies was higher than that observed in single group studies. The cumulative odds ratio for the study sample was 8.72 (95\% CI 4.78-15.91) ( $Z=7.07 ; \mathrm{p}<0.00001)$. They concluded that there is enough evidence to suggest a possible role of Helicobacter species in hepatobiliary tract cancers. However, differences were apparent among different regions of the world, method of Helicobacter detection, sub site of cancer within the hepatobiliary tract and choice of controls thus introducing heterogeneity (Table 1 and 2). ${ }^{11-23}$

There is a great difference in the prevalence of gall bladder carcinoma between patients in North and South India. Higher prevalence of cholesterol stones in the North Indian population and presence of heavy metals in the water and soil of the Indo Gangetic plains have been postulated as the reason for the same..$^{24,25}$ Absence of H. pylori maybe one of the factors for the low incidence of gall bladder carcinoma in South India. However, large studies, with control groups and a correlation between gastric and gall bladder $H$. pylori colonization need to be carried out before excluding $H$. pylori as a pathogenic entity in gallbladder disease in this population.

\section{Conclusion}

H. pylori was not found in gall bladder of patients with benign gall bladder disease in South Indian population. This finding is in contrast to studies done in North India.

\section{References}

1. O'Connor A, O'Morain CA, Ford AC. Population screening and treatment of Helicobacter pylori infection. Nat Rev Gastroenterol Hepatol. 2017;14(4):230-240.

2. Moricz A, Melo M, Castro A M et al, Prevalence of Helicobacter spp in chronic cholecystitis and correlation with changes on the histological pattern of the gallbladder. Acta Cir Bras [Internet]. 2010;25(3):218-24.

3. Shukla H S, Tiwari M. Discovery of Helicobacter pylori in gallbladder. Indian Journal of Gastroenterol. 2012:31(2):55-56.

4. Bansal, VK, Misra MC, ChaubalG. et al.Helicobacter pylori in gallbladder mucosa in patients with gallbladder disease. Indian J Gastroenterol. 2012:31:57.

5. Testerman TL. Beyond the stomach: An updated view of Helicobacter pylori pathogenesis, diagnosis, and treatment. World J Gastroenterol. 2014;20(36):12781.

6. Mishra RR, Tiwari M, Shukla HS. Helicobacter pylori and pathogenesis of gallbladder cancer. $J$ Gastroenterol Hepatol. 2011;34(7)449-53.

7. Deeba J, Singhal S, Malik A et al. Helicobacter pylori in gall bladder disease. Biomedical Research. 2010;21(4):437440.

8. Misra V, Misra SP, DwivediM, et al.Helicobacter pylori in areas of gastric metaplasia in the gallbladder and isolation of $H$. pylori DNA from gallstones. Pathology. 2007:39(4):419-24.

9. Chaudhary PK, Goyal S, Mahajan NC et al. Incidence of presence of $H$. pylori in cases of cholecystitis and cholelithiasis in a rural medical college \& hospital. J Drug Delivery Therap. 2015;5(5):5-8.

10. Pandey M, Shukla M.Helicobacter species are associated with possible increase in risk of hepatobiliary tract cancers. Surgical Oncol. 2009;18:51-56.

11. Fox JG, Dewhirst FE, Shen Z, Feng Y et al. Hepatic Helicobacter species identified in bile and gallbladder tissue from Chileans with chronic cholecystitis. Gastroenterology. 1998;114(4):755-63.

12. Myung SJ, Kim MH, Shim KN, et al, Detection of Helicobacter pylori DNA in human Biliary Tree and its association with hepatolithiasis. Dig Dis Sci. 2000;45(7):1405-12.

13. Leong RW, Sung JJY. Helicobacter species and hepatobiliary diseases. Aliment Pharmacol and Therap. 2002;16:1037-45.

14. Matsukura N, Yokomuro S, Yamada S, et al. Association between Helicobacter bilis in bile and biliary tract malignancies: H. bilis in bile from Japanese and Thai patients with benign and malignant diseases in the biliary tract. Jpn J Cancer Res. 2002;93(7):842-7.

15. Silva CP,Pereira-Lima JC, OliveiraetAG, et al. Association of the Presence of Helicobacter in Gallbladder Tissue with Cholelithiasis and Cholecystitis, J Clin Microbiol. 2003;41(12):5615-18.

16. Chen W, Li D, Cannan RJ, etal.Common presence of Helicobacter DNA in the gallbladder of patients 
with gallstone diseases and controls. Dig Liver Dis. 2003;35(4):237-43.

17. Farshad SH, Alborzi A, Malek Hosseini SA, et al. Identification of Helicobacter pylori DNA in Iranian patients with Gallstones. Epidemiol. Infect. 2004;132:1185-9.

18. Abayli B, Colakoglu S, Serin M, et al. Helicobacter pylori in the etiology of cholesterol gallstones. J Clin Gastroenterol. 2005;39(2):134-7.

19. Kobayashi T, Harada K, Miwa K, et al. Helicobacter Genus DNA Fragments Are Commonly Detectable in Bile from Patients with Extrahepatic Biliary Diseases and Associated with Their Pathogenesis. Dig Dis Sci. 2005;50(5):862-7.

20. Bohr URM, Kuester D, Meyer F, et al. Low prevalence of Helicobacteraaceae in gall stone disease and gall bladder carcinoma in the German population, Clin Microbiol Infect. 2007;13:525-31.
21. Griniatsos J, Sougioultzis S, Giaslakiotis K, et al. Does Helicobacter Pylori Identification in the Mucosa of the Gallbladder Correlate with Cholesterol Gallstone Formation? West Indian Med J. 2009;58(5):428-32.

22. Karagin PH, Stenram U, Wadstrom T, et al.Helicobacter species and common gut bacterial DNA in gallbladder with cholecystitis, World J Gastroenterol. 2010;16(38): 4817-22.

23. Yakoob J, Khan MR, Abbas Z, et al Helicobacter pylori: Association with gall bladder disorders in Pakistan, British Journal of Biomedical Science. 2011;68:2;56-64.

24. Behari A, Kapoor VK. Does gallbladder cancer divide India? Indian J Gastroenterol. 2010:29(1):9-13.

25. Sachidananda S, Krishnan AK, Janani K, et al. Characteristics of Gallbladder Cancer in South India, Indian J Surg Oncol. 2012;3(3):228-230. 